\title{
PERALIHAN HAK MILIK ATAS TANAH YANG BERASAL DARI WARISAN
}

\author{
Oleh : Amin Slamet
}

Dosen Fakultas Hukum Universitas 17 Agustus 1945 Samarinda

\section{ABSTRACT}

The purpose of this research is: First, to find out the implementation of the transfer of ownership of the inherited land in Samarinda. Second, to find out the inhibiting factors in the registration of the transfer of title to inherited land in Samarinda.

To find out the purpose above, then determined the research method is The Qualitative Descriptive Method, with sampling techniques by purposive sampling. Data collection techniques such as interviews with observations and study documents relevant to the problem under study.

Therefore it is hoped that the National Land Agency as the only body that regulates land in Indonesia is expected to be able to better socialize land regulations so that people can better understand the importance of registering land rights transfers using deeds to provide legal certainty and protection for right holders. as well as the main purpose of land registration itself.

\section{Keywords: Land Ownership, Inheritance}

\section{PENDAHULUAN}

\section{A. Latar Belakang}

Fungsi tanah begitu penting dan mempunyai arti sendiri, sebab tanah merupakan modal bagi kehidupan suatu keluarga. Selain itu tanah juga selalu digunakan untuk berbagai kegiatan manusia, seperti tempat tinggal, mendirikan bangunan, bahkan sampai manusia meninggal dunia membutuhkan tanah.

Tanah merupakan salah satu faktor penting dalam kehidupan manusia. Manusia dan tanah memiliki hubungan yang sangat erat, sangat alami dan tidak terpisahkan dan karena sebagian besar sumber kehidupan rakyat masih bersifat agraris, baik sebagai sumber hidup maupun sebagai wadah, banyak kita temui aktivitas seputar pertanahan seperti penambahan aset berupa rumah dan tanah. 
Adanya hubungan yang erat antara manusia dengan tanah, karena tanah merupakan tempat berpijak dan melakukan kelangsungan hidup sehari-hari. Maka manusia berlomba-lomba untuk menguasai dan memiliki bidang tanah yang diinginkan karena tanah mempunyai nilai ekonomis di segala aspek kehidupan manusia.

Untuk menciptakan kemakmuran dan kesejahteraan rakyat seperti yang diinginkan bangsa Indonesia, maka permasalahan yang berkaitan dengan penggunaan, pemilikan penguasaan dan peralihan hak atas tanah memerlukan perhatian yang khusus dalam peraturan perundangan.

Menyadari semakin meluasnya aktivitas masyarakat dalam berbagai bidang dan semakin bertambahnya penduduk dan kebutuhan manusia akan tanah menyebabkan kedudukan tanah yang sangat penting terutama dalam penguasaan, penggunaannya dan kepemilikannya.

Khususnya hal ini semakin majunya aktivitas ekonomi, maka banyak tanah yang tersangkut di dalamnya, meluasnya aktivitas itu yang umumnya berupa bertambah banyaknya jual beli, sewa menyewa, pewarisan, pemberian kredit bahkan juga timbulnya hubungan hukum dengan orang atau badan hukum asing.

Kenyataan ini menunjukkan bahwa kedudukan dan peranan hak atas tanah dalam masyarakat Indonesia sangatlah penting. Karena pentingnya kedudukan dan peranan tanah maka sering menimbulkan masalah. Seperti halnya mendirikan bangunan perumahan di kawasan hijau, pemilikan tanah secara absente, adanya sertifikat ganda, dan masalah tanah waris. Oleh karenanya upaya dalam mengatasi permasalahan di bidang pertanahan yaitu dengan jalan memberikan jaminan hukum dan kepastian hak dalam bidang pertanahan dan agraria.

Jaminan kepastian hukum mengenai penguasaan atau peralihan hak-hak atas tanah oleh seseorang yang diperoleh dari warisan merupakan perpindahan suatu hak atas tanah kepada orang lain. Yang dimaksudkan dari peneliti disini adalah kepemilikan hak atas tanah yang diperoleh dari pewaris kepada ahli waris. Maka perpindahan hak atas berarti subyek hak yaitu pewaris dan ahli waris, perlu dilaksanakan pendaftaran peralihan hak untuk mendapatkan jaminan kepastian hukum kepemilikan hak atas tanah.

Untuk menjamin kepastian hukum kepemilikan hak atas tanah warisan khususnya pada peralihan hak atas tanah warisan perlu diatur dalam suatu peraturan perundang-undangan, khususnya diatur dalam Undang-Undang Pokok Agraria (UUPA).

Landasan dasar bagi pemerintah dan rakyat Indonesia untuk menyusun politik hukum serta kebijaksanaan di bidang pertanahan yang telah tertuang dalam Undang-Undang Dasar 1945 pasal 33 ayat (3) yang berbunyi sebagai berikut: "Bumi, air dan kekayaan alam yang terkandung 
di dalamnya dikuasai oleh negara dan dipergunakan untuk sebesar-besar kemakmuran rakyat".

Ketentuan ini dijabarkan dalam Undang-Undang Pokok Agraria pasal 2 yang menyatakan bahwa "Bumi, air dan ruang angkasa termasuk kekayaan alam yang tekandung di dalamnya itu pada tingkatan tertinggi dikuasai oleh negara sebagai organisasi kekuasaan seluruh rakyat".

Berdasarkan ketentuan dalam Undang-Undang Dasar 1945 pasal 33 ayat (3) dan Undang-Undang Pokok Agraria tahun 1960 pasal 2 di atas, maka ada dua hal penting yang merupakan negara mempunyai kekuasaan atas tanah. Selanjutnya apabila hal ini dikaitkan dengan asas-asas perikemanusiaan dan keadilan sosial di dalam Pancasila akan diperoleh suatu pengertian mengenai hubungan antara negara dengan tanah yang dimasukkan dalam kekuasaan negara pada umumnya mengenai aturan yang bersangkutan dengan hidup bersama.

Dari sumber materi konsultasi maupun konsultasi hukum melalui narasumber terlihat selalu saja ada pertanyaan seputar masalah pertanahan. Tidak memandang dari segmen masyarakat bawah, menengah hingga atas, mulai dari masyarakat yang memiliki tingkat pendidikan yang rendah hingga pendidikan yang tinggi, tetap saja masalah pertanahan muncul.

Melihat kenyataan seperti itu, muncul suatu pertanyaan mengapa masih banyak permasalahan seputar pertanahan ? Apakah banyaknya permasalahan di bidang pertanahan tersebut diakibatkan oleh ketidak tahuan masyarakat atau kurangnya kesadaran masyarakat akan hak dan kewajibannya terkait tanah atau malah karena kurangnya sosialisasi di bidang pertanahan?

Guna mewujudkan maksud yang terkandung dalam Pasal 33 ayat 3 UUD 1945, Pemerintah Indonesia pada tanggal 24 September 1960 menggunakan Undang-Undang Nomor 5 Tahun 1960 tentang Peraturan Dasar Pokok Agraria (UUPA).

Tujuan dikeluarkannya Undang-Undang Pokok Agraria ini adalah:

1. Melekatkan dasar-dasar bagi penyusunan hukum Agraria nasional, yang merupakan alat untuk membawa kemakmuran kebahagian dan keadilan bagi negara dan rakyat, dalam rangka masyarakat adil dan makmur.

2. Meletakkan dasar-dasar untuk mengadakan kesatuan dan kesederhanaan dalam hukum pertanahan.

3. Meletakkan dasar-dasar untuk memberikan kepastian hukum mengenai hak-hak atas tanah bagi rakyat seluruhnya.

Pemberian hak atas tanah ini dimaksudkan untuk memberi wewenang kepada yang memperoleh hak untuk mempergunakan tanah tersebut, sebaik-baiknya menurut hukum. 
Macam-macam hak atas tanah yang dapat diberikan kepada orang atau badan hukum dimaksud sebagai berikut :

1. Hak Milik

2. Hak Guna Usaha

3. Hak Guna Bangunan

4. Hak Pakai

5. Hak Sewa

6. Hak Membuka Tanah

7. Hak Memungut Hasil Hutan

8. Hak-hak yang lain yang tidak termasuk hak-hak tersebut di atas, yang akan ditetapkan dengan Undang-Undang serta hak-hak yang sifatnya sementara seperti yang disebut dalam Pasal 53 ayat 1 UUPA.

Dari aneka jenis hak atas tanah yang diatur dalam UUPA, hak milik (pasal 23), hak guna usaha (Pasal 32), dan hak guna bangunan (Pasal 38) adalah hak-hak yang harus didaftarkan pada Badan Pertanahan Nasional (BPN).

Tujuan dari pendaftaran tanah dan hak-hak atas tanah serta peralihan hak-hak tersebut untuk menjamin kepastian hukum yang bersifat rechtscadaster. Rechtscadaster artinya untuk kepentingan pendaftaran tanah saja dan hanya mempermasalahkan haknya apa dan siapa pemiliknya, bukan untuk kepentingan lain seperti perpajakan.

Di dalam Pasal 1 Undang-Undang Pokok Agraria tersebut diatas ditentukan bahwa pelaksanaan pendaftaran tanah akan diatur dalam Peraturan Pemerintah, yang sekarang berlaku Peraturan Pemerintah Nomor 24 tahun 1997 tentang Pendaftaran Tanah, dan sudah mulai berlaku sejak ditetapkannya sebagai peraturan pelaksanaan ketentuan pasal Undang-Undang Pokok Agraria tersebut.

Pendaftaran tanah yang kita ketahui selain berfungsi untuk melindungi pemilik, juga memiliki fungsi untuk mengetahui status kepemilikan sebidang tanah, siapakah pemiliknya, berapa ukuran luasnya, dan untuk apa dipergunakan. Oleh karena itu agar pelaksanaan peralihan penguasaan atau kepemilikan hak dari Negara atau masyarakat atas tanah di Indonesia tidak menimbulkan berbagai masalah maupun sengketa mengenai kepentingan-kepentingan terhadap tanah, maka diperlukan pengaturan yang tegas dan landasan hukum yang kuat di bidang pertanahan.

Bahwa dengan ditetapkannya kewenangan serta tugas yang dimiliki pemerintah mengenai bidang pertanahan ini telah memberikan konsekuensi bahwasanya pemerintah harus membuat kebijaksanaan dalam rangka membentuk peraturan khususnya di bidang agraria. 
Sebagaimana dinyatakan dalam Undang-Undang Pokok Agraria Nomor 5 Tahun 1960 pasal 19 ayat (1) yang berbunyi sebagai berikut "Untuk menjamin kepastian hukum oleh pemerintah diadakan pendaftaran tanah di seluruh wilayah Republik Indonesia menurut ketentuan yang diatur dengan Peraturan Pemerintah".

Dalam hal ini Pemerintah telah mengeluarkan Peraturan Pemerintah Nomor 24 Tahun 1997 tentang pendaftaran tanah. Kemudian adapun yang bertugas untuk melakukan pendaftaran peralihan hak atas tanah yang ada sekarang ini ditangani oleh Badan Pertanahan Nasional.

Bahwa dengan melihat ketentuan pasal 19 Undang-Undang Pokok Agraria tersebut, pendaftaran hak atas tanah sangat penting sebab tanah yang telah didaftarkan akan mendapatkan Surat Tanda Bukti Pemilikan Tanah yang disebut sertifikat. Karena sertifikat tanah ini merupakan hak atas tanah yang mempunyai kekuatan dan kepastian hukum yang tetap.

Sertifikat tanah yang diberikan itu akan memberikan arti dan peranan penting bagi pemegang hak yang bersangkutan yang berfungsi sebagai alat bukti atas tanah, terutama jika terjadi persengketaan terhadap tanah. Salah satu pelayanan yang diberikan Kantor Pertanahan Kota Samarinda kepada masyarakat di bidang pertanahan adalah pencatatan peralihan hak terus menerus berusaha memberikan informasi agar tahaptahap pelaksanaan kegiatan baik yang menyangkut dari aspek teknis, administrasi dan yuridis dapat berjalan dengan baik, lancar dan memuaskan.

Namun demikian dalam kenyataannya masih banyak warga kota Samarinda yang dalam melakukan peralihan hak atas tanah belum didaftarkan peralihannya ke pelayanan pendaftaran peralihan hak atas tanah warisan di Badan Pertanahan Nasional kota Samarinda.

\section{B. Perumusan Masalah}

1. Apakah masalah dalam pelaksanaan peralihan hak atas tanah karena warisan?

2. Bagaimanakah upaya yang dilakukan dalam penanggulangan hambatan yang terjadi dalam pelaksanaan pendaftaran tanah ?

\section{KERANGKA DASAR TEORI}

\section{A. Tinjaun Yuridis Tentang Hukum Waris}

Hukum Waris merupakan bagian dari hukum kekeluargaan, memegang peranan penting bahkan menentukan dan mencerminkan sistem kekeluargaan yang berlaku dalam masyarakat. Hal ini disebabkan 
hukum waris itu sangat erat kaitannya dengan ruang lingkup kehidupan manusia, sebab setiap manusia pasti akan mengalami suatu peristiwa yang sangat penting dalam hidupnya yang merupakan peristiwa hukum dan lazim disebut meninggal dunia. Meninggalnya seseorang menimbulkan akibat hukum, tentang bagaimana kelanjutan pengurusan hak-hak dan kewajiban-kewajiban seseorang yang telah meninggal dunia itu.

Penyelesaian dan pengurusan hak-hak dan kewajiban seseorang sebagai akibat adanya peristiwa hukum karena meninggalnya seseorang diatur oleh hukum waris. Hukum waris itu dapat dikatakan sebagai himpunan dan peraturan-peraturan hukum yang mengatur bagaimana caranya pengurusan hak-hak dan kewajiban seseorang yang meninggal dunia oleh ahli waris atau badan hukum lainnya.

Hukum waris itu memuat peraturan-peraturan yang mengatur proses meneruskan serta mengoperkan barang-barang atau harta benda dan barang-barang yang tidak berwujud benda dari suatu angkatan manusia kepada keturunannya, cara penerusan dan peralihan harta kekayaan dari waris kepada ahli warisnya dapat berlaku sejak pewaris masih hidup atau setelah pewaris meninggal dunia.

Dalam proses pewarisan hal yang terpenting adalah adanya kematian, yaitu seorang yang meninggal dunia dan meninggalkan kekayaan itu kepada ahli warisnya. Hukum waris, disamping mengatur proses pewarisan, juga mengatur ahli waris yang berhak menerima harta warisan, baik yang bersifat material maupun immaterial. Harta warisan menurut hukum adat tidak merupakan kesatuan yang dapat dinilai harganya, tetapi merupakan kesatuan yang dapat dinilai harganya, tetapi merupakan kesatuan yang dapat dibagi-bagi atau tidak dapat dibagi-bagi menurut jenis dan kepentingan para ahli waris.

Istilah hukum waris diatas mengandung suatu pengertian yang mencakup kaidah-kaidah dan asas-asas yang mengatur proses beralihnya harta benda dan hak-hak serta kewajiban-kewajiban setiap orang yang meninggal dunia, tetapi ada juga hak dan kewajiban yang tidak dapat diwariskan kepada ahli warisnya yaitu hak dan kewajiban seorang lakilaki selaku ayah maupun selaku suami terhadap istri maupun anakanaknya, selain itu pula hak dan kewajiban seseorang sebagai anggota dari suatu organisasi atau perkumpulan sosial maupun perkumpulanperkumpulan komersial yang hanya bertujuan untuk mencari keuntungan belaka.

Dalam hal membicarakan pewaris, ahli waris, dan harta warisan, maka berpindahnya hak dan kewajiban kepada ahli waris adalah pasti terjadi dalam kehidupan manusia. Seorang ahli waris diberi kesempatan untuk menerima, menolak atau menerima dengan syarat tidak akan membayar hutang-hutang pewaris melebihi bagiannya dalam harta 
warisannya, namun dalam kehidupan di masyarakat menolak atau menerima dengan syarat adalah hal yang tidak lazim dilakukan.

Sekalipun ternyata warisan yang diterima oleh ahli waris adalah beban-beban dan kewajiban-kewajiban, yaitu hutang-hutang dari pewaris, namun pada kenyataan warisan yang demikian tetap diterima secara penuh. Walaupun memberatkan, hal ini diterima oleh ahli waris, terutama untuk menjaga nama baik orang tuanya (pewaris), sekaligus sebagai bukti seseorang berbakti kepada orang tua.

\section{B. Tinjauan Hukum Tentang Pendaftaran Tanah \\ 1. Pengertian Tanah.}

Tanah merupakan hal yang sangat kompleks karena menyangkut banyak segi kehidupan masyarakat. Setiap orang hidup membutuhkan tanah, baik sebagai tempat tinggal maupun tempat usaha. Semakin meningkatnya jumlah penduduk, semakin meningkat pula kebutuhan atas tanah, padahal luas tanah wilayah negara adalah tetap atau terbatas. Dalam pasal 1 ayat (4) UUPA ditentukan, dalam pengertian bumi selain permukaan bumi, termasuk pula tubuh bumi dibawahnya serta yang berada di bawah air. Berdasarkan ketentuan pasal tersebut, maka bumi itu sendiri dapat dibedakan menjadi :

a. Permukaan bumi.

b. Tubuh bumi serta yang berada di bawah air.

Selanjutnya dalam Pasal 4 ayat (1) UUPA ditentukan bahwa atas dasar hak menguasai dari negara sebagai yang dimaksud dalam Pasal 2 ditentukan adanya macam-macam hak atas permukaan bumi yang disebut dengan "tanah" hanya permukaan bumi yang merupakan bagian kecil dari sumber daya alam agraria.

\section{Pengertian Peralihan Hak Atas Tanah}

Tanah dapat dinilai sebagai suatu harta yang mempunyai sifat tetap, sebagai tempat dan sumber penghidupan. Dewasa ini banyak terjadi peralihan hak atas tanah tanpa dilakukan pendaftaran tanah. Hal ini disebabkan karena kurangnya pengertian dan kesadaran masyarakat tentang arti pentingnya akta peralihan hak atas tanah. Kejadian semacam ini hampir sering terjadi di seluruh wilayah Indonesia. Salah satu sebab terjadinya peralihan hak adalah karena adanya peristiwa pewarisan. Peralihan hak atas tanah adalah merupakan peralihan hak atas tanah dari seseorang kepada orang lain, salah satunya dengan pewarisan. Dengan demikian peralihan hak adalah merupakan perbuatan hukum yang terjadi secara otomatis dikarenakan adanya peristiwa kematian. Maka hak pewaris langsung beralih kepada ahli warisnya, artinya peralihan hak terjadi dengan tidak disengaja. 
Sedangkan pemindahan hak dilakukan dengan sengaja, misalnya pemindahan hak dengan jual beli.

\section{Peralihan Hak Milik Atas Tanah Karna Warisan}

Perolehan hak milik atas tanah dapat juga terjadi karena pewarisan dari pemilik kepada ahli waris sesuai dengan Pasal 26 Undang-Undang Pokok Agraria. Dalam perkembangannya, peralihan hak karena pewarisan telah mendapat penegasan pada Bab V, Paragraf 3 tentang peralihan hak karena pewarisan sebagaimana tersebut dalam Pasal 42 Peraturan Pemerintah Nomor 24 Tahun 1997, yakni sebagai berikut :

a. Untuk pendaftaran peralihan hak karena pewarisan mengenai bidang tanah hak yang sudah didaftar sebagai yang diwajibkan menurut ketentuan sebagaimana dimaksud dalam Pasal 36, wajib diserahkan oleh yang menerima hak atas tanah atau hak milk atas satuan rumah susun yang bersangkutan sebagai warisan kepada kantor pertanahan, sertipikat hak yang bersangkutan, surat kematian orang yang namanya dicatat sebagai pemegang hanya dan surat tanda bukti sebagai ahli waris. Peralihan hak karena pewarisan terjadi karena hukum pada saat yang bersangkutan meninggal dunia. Dalam arti, bahwa sejak itu para ahli waris menjadi pemegang hak yang baru. Mengenai siapa yang menjadi ahli waris diatur dalam hukum perdata yang berlaku.

Pendaftaran peralihan hak karena pewarisan juga diwajibkan dalam rangka memberikan perlindungan hukum kepada para ahli waris dan demi ketertiban tata usaha pendaftaran tanah. Surat tanda bukti sebagai ahli waris dapat berupa akta keterangan hak mewaris, atau surat penetapan ahli waris atau surat keterangan ahli waris.

b. Jika bidang tanah yang merupakan warisan belum didaftar, wajib diserahkan juga dokumen-dokumen sebagaimana dimaksud dalam Pasal 39 ayat (1) huruf b yaitu surat keterangan kepala desa/kelurahan yang menyatakan yang bersangkutan menguasai tanah, dan surat keterangan yang menyatakan bahwa bidang tanah tersebut belum bersertifikat dari kantor pertanahan, atau surat keterangan kepala desa/lurah jika lokasi tanahnya jauh dari kedudukan kantor pertanahan dari pemegang hak yang bersangkutan. Dokumen yang membuktikan adanya hak atas tanah pada yang mewariskan diperlukan karena pendaftaran peralihan hak ini baru dapat dilakukan setelah pendaftaran untuk pertama kali atas nama pewaris.

c. Jika penerima warisan terdiri dari satu orang, pendaftaran peralihan hak tersebut dilakukan kepada orang tersebut 
berdasarkan surat tanda bukti sebagai ahli waris sebagaimana dimaksud pada ayat (1).

Jika penerimaan warisan lebih dari satu orang dan waktu peralihan hak tersebut didaftarkan disertai dengan akta pembagian waris yang memuat keterangan bahwa hak atas tanah atau hak milik atas satuan rumah susun tertentu jatuh kepada seorang penerima warisan tertentu, pendaftaran peralihan hak milik atas tanah atau hak milik atas satuan rumah susun itu dilakukan kepada penerima warisan yang bersangkutan berdasarkan surat tanda bukti sebagai ahli waris dan akta pembagian waris tersebut. Dalam hal akta pembagian waris dapat dibuat sesuai ketentuan yang berlaku, dan harta waris jatuh pada seorang penerima warisan tertentu, pendaftaran peralihan haknya dapat langsung dilakukan tanpa alat bukti peralihan hak lain, misalnya akta PPAT.

Warisan berupa hak atas tanah yang menurut akta pembagian waris harus dibagi bersama antara beberapa penerima warisan atau waktu didaftarkan belum ada akta pembagian warisnya, didaftar peralihan haknya kepada para penerima waris yang berhak sebagai hak bersama mereka berdasarkan surat tanda bukti sebagai ahli waris dan/atau akta pembagian waris tersebut.

Sesudah hak tersebut didaftar sebagai harta bersama, pendaftaran pembagian hak tersebut dilakukan berdasarkan ketentuan Pasal 51, dimana pembagian hak bersama atas tanah menjadi hak masing-masing pemegang hak bersama didaftar berdasarkan akta PPAT yang berwenang menurut peraturan yang berlaku yang membuktikan kesepakatan antara pemegang hak bersama mengenai pembagian hak bersama tersebut. Suatu hak bersama yang diperoleh dari warisan perlu dibagi sehingga menjadi hak individu. Kesepakatan antara pemegang hak bersama tersebut perlu dituangkan akta PPAT yang akan menjadi dasar pendaftarannya.

Dalam pembagian tersebut, tidak harus semua pemegang hak bersama memperoleh bagian. Dalam pembagian harta waris sering kali yang menjadi pemegang hak individu hanya sebagian dari keseluruhan penerima warisan, asalkan hak tersebut disepakati oleh seluruh penerima warisan sebagai pemegang hak bersama.

\section{III.PEMBAHASAN}

\section{A. Masalah dalam Pelaksanaan Pendaftaran Peralihan Hak Milik Atas Tanah Yang Berasal Dari Warisan. \\ Masalah dalam pelaksanaan pendaftaran peralihan hak milik karena warisan yaitu :}

1. Dari masyarakat 
Berdasarkan dari penelitian yang telah dilaksanakan masih banyak yang belum mengetahui pentingnya pendaftaran hak milik atas tanah, dan pada saat pengajuan permohonan pendaftaran peralihan hak milik atas tanah belum melengkapi syarat-syarat yang ditentukan oleh pemerintah. Dan masih ada yang belum mengerti pentingnya pendaftaran peralihan hak milik atas tanah guna kepastian tanah.

Oleh sebab itu masyarakat perlu diadakannya penyuluhan yang dilakukan oleh kantor pertanahan, guna kelancaran pelaksanaan pendaftaran peralihan hak milik atas tanah karena warisan. Sehingga masih banyak orang yang enggan untuk melakukan peralihan hak milik atas tanahnya karena ketidaktahuan mereka mengenai pelaksanaan peralihan hak milik atas tanah karena warisan. Ketidak tahuan warga masyarakat atas syarat-syarat yang dibutuhkan pemohon dalam melaksanakan peralihan hak milik atas tanahnya. dan juga pemohon peralihan seringkali dilakukan pada saat akan dijual sehingga peralihan harus segera dilakukan.

Selain itu penyebab yang lain yaitu kurangnya pemahaman mengenai sertipikat tanah yang dapat dijadikan bukti yang kuat apabila terjadi masalah mengenai kepemilikan tanah pada nantinya. Sehingga apabila nantinya terjadi masalah dapat mnunjukkan bukti yang telah kita miliki.

2. Dari kantor pertanahan

Yaitu apabila pada saat proses pendaftaran peralihan hak milik atas tanah karena warisan, data yang dibutuhkan belum dilengkapi oleh pemohon. Kendala lain yang dihadapi oleh kantor pertanahan adalah apabila saat berjalannya proses peralihan hak ada yang tidak termasuk atas pengajuan peralihan hak atas tanah yang diperoleh dari pewarisan dengan alasan tertentu, misalnya : syarat yang diajukan terdapat pemalsuan tanda tangan, tidak terima mengenai bagian harta. Untuk itu seharusnya kantor pertanahan melakukan perubahan-perubahan yang dapat meningkatkan kualitas dan kuantitas pegawai kantor pertanahan.

\section{B. Upaya Yang Dilakukan Dalam Pelaksanaan Pendaftaran Peralihan Hak Milik Atas Tanah Yang Berasal Dari Warisan}

Sedangkan upaya yang dilakukan dalam mengantisipasi dan menangani kendala yang dihadapi dalam pelaksanaan peralihan hak milik atas tanah peralihan hak milik atas tanah karena waris yaitu :

1. Masyarakat pemegang hak yang baru apabila dalam pengajuan permohonan peralihan hak karena warisan harus melengkapi persyaratan yang telah ditentukan oleh pemerintah. Hal ini dapat diketahui dari pejabat kantor pertanahan yang menyebutkan bahwa banyak sekali dalam pelaksanaan pendaftaran hak milik atas tanah 
karena pewarisan yang kurang persyaratannya dalam pelaksanaan pendaftaran peralihan hak atas tanah yang diajukan. Oleh karena itu sebaiknya dalam pelaksanaannya seharusnya masyarakat ikut aktif dalam kelancaran pelaksanaan pendaftaran peralihan hak milik atas tanah karena warisan. Dan apabila kurang mengerti mengenain persyaratan yang digunakan dapat menanyaan pada kantor pertanahan bagian informasi yang telah tersedia disana.

2. Untuk kantor pertanahan dengan melakukan penyuluhan secara rutin dan penyebarluasan informasi pertanahan dilaksanakan oleh kantor pertanahan baik mengenai informasi pendaftaran tanah, peraturanperaturan pertanahan, dan pentingnya pendaftaran peralihan hak milik atas tanah guna menjamin kepastian hukum bagi pemegang hak milik atas tanah.

Selain dilakukan penyuluhan-penyuluhan guna kelancaran pada saat proses pendaftaran peralihan hak milik atas tanah karena warisan juga ditunjang dengan kualitas para pegawai yang ada pada kantor pertanahan. Oleh karena itu hendaknya para pegawai memenuhi kualitas guna menunjang pelaksanaan pendaftaran peralihan hak milik atas tanah karena warisan dapat berjalan dengan baik dan lancar.

\section{A. Kesimpulan}

\section{PENUTUP}

1. Masalah dalam pelaksanaan pendaftaran peralihan hak milik atas tanah karena pewarisan yaitu :

a. Masalah yang berasal dari masyarakat yaitu pemohon pendaftaran hak masih kurang melengkapi persyaratan yang dibutuhkan dalam melaksanakan pendaftaran peralihan hak milik atas tanah karena pewarisan. Bagi masyarakat pemegang hak untuk mengatasi kendala dalam pelaksanaan peralihan yaitu dengan melengkapi persyaratan yang telah ditentukan oleh pemerintah.

b. Masalah yang dihadapi kantor pertanahan adalah pada saat proses pendaftaran peralihan hak milik atas tanah karena pewarisan yaitu mengenai persyaratan yang harus dilengkapi dalam pengajuan pendaftaran peralihan hak milik atas tanah karena pewarisan sehingga sering menghambat dalam penyelesaiannya. Kendala lain yang harus dihadapi oleh kantor pertanahan yaitu apabila saat penyelesaian peralihan tersebut ada pihak yang mengajukan keberatan terhadap peralihan hak yang didaftarkan. hal ini juga dapat menghambat penyelesaian peralihan hak.

2. Sedangkan upaya yang dilakukan oleh kantor pertanahan dalam mengantisipasi dan menangani kendala dalam pelaksanaan 
pendaftaran peralihan hak milik atas tanah karena pewarisan yaitu dengan melakukan penyuluhan-penyuluhan secara rutin, menyebarkluaskan informasi mengenai kewajiban mendaftarkan setiap peralihan hak milik guna untuk menjamin kepastian hukum bagi pemegang hak milik yang baru. Apabila terjadi keberatan dalam pelaksanaan peralihan hak milik atas tanah ,maka diselesaikan secara intern dan apabila tidak ada jalan keluarnya, maka biasanya kantor pertanahan melimpahkannya ke pengadilan, setelah ada putusan dari pengadilan baru kantor pertanahan memproses kembali peralihan hak tersebut.

\section{B. Saran}

1. Masyarakat khususnya pemegang hak milik atas tanah dalam pengajuan pelaksanaan pendaftaran peralihan hak milik atas tanah karena pewarisan sebaiknya lebih teliti dan cermat dalam melengkapi persyaratan yang telah ditentukan oleh pemerintah sehingga kinerja pejabat yang berwenang akan lebih efisien.

2. Segala bentuk peralihan sebaiknya didaftarkan guna menjamin kepastian hukum bagi pemegang hak milik yang baru.

3. Diharapkan kantor pertanahan untuk lebih sering mengadakan penyuluhan ke desa-desa secara menyeluruh, agar masyarakat lebih memahami akan pentingnya pendaftaran tanah guna menjamin kepastian hukum bagi pemegang haknya.

\section{DAFTAR PUSTA}

AP.Perlindungan, Pendaftaran Tanah Di Indonesia, Aditya, Bandung, 2001.

Abdulkadir Muhammad, Hukum Waris ,2000

Bachtiar Effendi, Pendaftaran Tanah Di Indonesia, Alumni, Bandung, 2000.

Boedi Harsono, Hukum Agraria Idonesia, Sejarah Pembentukan UUPA, isi dan pelaksanaan, Djambatan 1999.

Chadidjah Dalimunthe, Pelaksanaan Landreform di Indonesia dan Permasalahannya, (Medan : FH USU Press) 2002

Hilman Hadikusuma, Hukum Waris Adat, Aditia, Bandung, 1999

H. Hadari Nawawi, Penelitian Terapan, Gajah Mada University Press, Yogyakarta, 2000. 
I.G.N. Sugangga, Hukum waris Adat, CV. Sumber Karya, Semarang, 2004 Masr Singarimbun, Metode penelitian Hukum, Liberty, Jakarta, 2000.

M. Idris Ramulyo ; Perbandingan Pelaksanaan Kewarisan Islam Menurut Hukum Perdata (BW) Jakarta, 1993

Plorianus SP Sangun, Tata Cara Mengurus Sertifikat Tanah, Visimedia, Cet.1, Jakarta, 2007

Sutedi Adrian, Peralihan Hak Atas Tanah dan Pendaftarannya, Sinar Grafika, Jakarta, 2006.

Abdurrahman Soejono, Prosedur Pendaftaran Tanah (Tentang Hak Milik, Hak Sewa Bangunan, Hak Guna Bangunan), Rineka Cipta, Jakarta.2001

Effendy Bachtiar, Pendaftaran Tanah Di Indonesia Dan Peraturan Pelaksanaannya, Alumni, Bandung, 2003.

Undang-Undang No. 5 Tahun 1960 Tentang Peraturan Dasar Pokok Agraria.

Peraturan Pemerintah No. 24 Tahun 1997 Tentang Pelaksanaan Administrasi Umum.

Peraturan Pemerintah Menteri Agraria No. 7 Tahun 1961 Tentang Penyelenggaraan Tata Usaha Pendaftaran Tanah.

Peraturan Menteri Agraria No. 3 Tahun 1997 Tentang Ketentuan Pelaksanaan PP No. 24 Tahun 1997 Tentang Pendaftaran Tanah. 